\title{
Trudne przywództwo w Europie O roli RFN we Wspólnocie Europejskiej
}

Pod koniec lat 80. XX stulecia kontynent europejski zmierzał w kierunku nieprzewidywalnych zmian. Podzielona na dwie części Europa miała stać się ponownie jednością. Symbolem jej powojennego podziału stał się rozpad państwa niemieckiego na dwa różne pod względem ustrojowym kraje - w świadomości Europejczyków utrwaliło się nawet przekonanie, że podział kontynentu istnieć będzie tak długo, jak podział Niemiec. Stąd zjednoczenie Niemiec miało tak duże znaczenie dla dalszej integracji europejskiej.

Upadek systemu komunistycznego wprowadził istotne zmiany na mapie Europy - rozpad Związku Radzieckiego i powstanie na jego miejsce piętnastu nowych krajów, reunifikacja Niemiec oraz rozwój demokracji i zasad wolnego rynku na wschód od Łaby zaowocowały koniecznością wprowadzenia poważnych modyfikacji w geopolitycznym układzie Europy i świata. Wprawdzie kiedy państwa Europy Środkowo-Wschodniej zaczynały bunt przeciwko systemowi komunistycznemu pod koniec lat 80., nie przypuszczano, że sprawujące kontrolę nad połową świata supermocarstwo przestanie istnieć. Niemniej nadzieja na lepsze jutro utożsamiane z gospodarką wolnorynkową i demokracją była na tyle mocna, iż zmiany stały się nieodwracalne.

W wyniku przemian geopolitycznych pozycję stracili dotąd najsilniejsi gracze na scenie europejskiej - Francuzi, których miejsce zaczęli przejmować Niemcy. Na początku ostatniej dekady XX wieku można było nawet odnieść wrażenie, że Republika Federalna Niemiec stała się nowym przywódcą Europy. Nie bez znaczenia dla jej pozycji pozostawała przewaga terytorialna, demograficzna i gospodarcza, jaką posiadała nad swym zachodnim sąsiadem, ale także nad pozostałymi państwami ${ }^{1}$. Dla Paryża wzrost znaczenia

F. Mitterrand, De l'Allemagne, de la France, Paris 1996, s. 60. Por: M. Stolarczyk, Podział i zjednoczenie Niemiec jako element ładów europejskich po drugiej wojnie światowej, Katowice 1995, s. 182-183. 
Niemiec na arenie międzynarodowej, w szczególności po podjęciu decyzji przez Bundestag o przeniesieniu stolicy do Berlina ${ }^{2}$, stanowił zaś duże wyzwanie. O ile bowiem Francuzi nie mieli nic przeciwko dwugłowemu przywództwu na kontynencie, które miało miejsce od lat 50. XX stulecia, choć $\mathrm{z}$ podkreśleniem ich roli $\mathrm{w}$ jednoczeniu kontynentu, o tyle samotne przewodnictwo nowej Republiki Federalnej oraz zmarginalizowanie roli Francji wydawało się im poważnym zagrożeniem. Tym bardziej, że Niemcy nie ustawali w poszukiwaniach nowych sojuszników pertraktując tak z upadającym ZSRR, jak i krajami wydobywającymi się spod jego kurateli. Obawiano się, iż Niemcy wybiorą własną Sonderweg, zdecydują się na neutralność lub zdominują całą Europę. Tymczasem najlepszym sposobem na utrzymanie ich w europejskiej konstelacji bez przesadnego podkreślania niemieckiej roli mogło okazać się stworzenie nowego systemu współpracy w Europie przewidującego powszechne rozbrojenie i likwidację podziału na dwa bloki polityczne, równość wszystkich krajów, określenie pozycji RFN bez szkody dla jego sąsiadów i utworzenie „wspólnego europejskiego domu”’.

Choć pojawiały się projekty całkowitego odłączenia się nowych Niemiec od koncepcji integracyjnych, w które RFN zaangażowana była już od pierwszych lat powojennych ${ }^{4}$, politycy chadeccy sprawujący władzę w okresie przełomu nie pozostawiali złudzeń, że ich podstawowym zadaniem jest nadanie Niemcom nowego, silnego statusu w jednoczącej się Europie. Republika Federalna już na początku lat 90 . opowiadała się za rozszerzeniem terytorialnym Wspólnot Europejskich oraz dalszym pogłębianiem integracji celem osiągnięcia wspólnego europejskiego ładu pokojowego (gesamteuropäiche Friedensord$n u n g)^{5}$. Jednak silne zaangażowanie Niemiec $\mathrm{w}$ integrację także budziło obawy

2 Szerzej: Eine wunderbare Katastrophe, „Der Spiegel”, 24.06.1991.

3 F. Bozo, J. Paolini, Trois Allemagnes, deux Europes et la France, „Politique étrangère”, 1990, nr 1, s. 119-138.

4 Opinię publiczną interesowała odpowiedź na pytanie, czy zjednoczone, silne Niemcy będą dążyć do budowania nowej jakości na scenie międzynarodowej i czy ta nowa jakość oznaczać będzie budowanie europejskich Niemiec, czy też niemieckiej Europy. T.G. Ash, W imieniu Europy. Niemcy i podzielony kontynent, Londyn 1996, s. 463-490.

5 Niemcy wielokrotnie podkreślali, że ich przywiązanie do idei integracji europejskiej jest silniejsze od pojawiających się głosów o nacjonalizacji polityki niemieckiej. Pragnąc podziękować za międzynarodową zgodę na zjednoczenie i dać wyraz swemu zaangażowaniu w sprawy europejskie, w trakcie szczytu Rady Europejskiej w Maastricht zrezygnowali z własnej, silnej waluty, celem zamiany jej na ogólnoeuropejski pieniądz. U. Leimbacher, Westeuropäische Integration und gesamteuropäische Kooperation, „Aus Politik und Zeitgeschichte” 1991, nr 45, s. 3-12. Także w artykule 
na europejskich salonach - planowane poszerzenie WE o kraje północne ${ }^{6}$ (Finlandię, Szwecję, Norwegię oraz Austrię) jedynie podsycało dyskusję nad wzmocnieniem niemieckiej opcji w nowej Europie. Nie mniejsze znaczenie przypisywano zaangażowaniu zjednoczonych Niemiec $\mathrm{w}$ proces integracji dawnych krajów komunistycznych ze Wspólnotą. Obawiano się wręcz politycznej, gospodarczej, a nawet militarnej ekspansji nowego mocarstwa ${ }^{7}$.

Powyższe obawy miały swoje uzasadnienie w faktach - zjednoczone Niemcy stały się zdecydowanie najsilniejszym ludnościowo krajem we Wspólnocie, $\mathrm{z}$ największym terytorium ${ }^{8}$. Pozycja „karty przetargowej” $\mathrm{w}$ grze supermocarstw uległa przedawnieniu, zaś okres podziału ideologicznego skończył się. Ponieważ zjednoczenie Niemiec zostało przeprowadzone na demokratycznej płaszczyźnie zaproponowanej przez Bonn, nowe państwo niemieckie stało się organizmem z silnie zakorzenioną tradycją egalitaryzmu, w którym stosunki dobrosąsiedzkie i integracja europejska mają najwyższą wartość 9 . Jednak siła polityczna nie szła $\mathrm{w}$ parze z możliwościami gospodarki - olbrzymie trudności z integracją społeczeństw znajdujących się przez dziesięciolecia po dwóch różnych stronach muru berlińskiego oraz wysokie koszty transformacji ustrojowej wynikające $\mathrm{z}$ nadziei na szybkie przystosowanie gospodarki dawnych Niemiec Wschodnich do tempa rozwoju zachodnich landów, przysparzały rządowi federalnemu trosk zarówno politycznych, jak i finansowych ${ }^{10}$. Mimo tego uważano, że zaangażowanie w sprawy europejskie przyczyni się do odbudowy dobrobytu i polepszenia poziomu życia mieszkańców państwa w sercu Europy. Nie bez znaczenia pozostawał fakt, że

dla „Frankfurter Allgemeine Zeitung” z 02.-03.10.1990 roku Helmut Kohl zapewnił, że aktywna polityka RFN na arenie międzynarodowej jest najważniejszym punktem polityki zagranicznej zjednoczonych Niemiec.

6 Szerzej: P. Hort, So weit Europa reicht, „Frankfurter Allgemeine Zeitung”, 03.03.1994.

7 B. Koszel, Mitteleuropa rediviva? Europa Środkowo- i Południowo-Wschodnia w polityce zjednoczonych Niemiec, Poznań 1999, s. 49-63.

8 Zgodnie z danymi z 1995 roku Republika Federalna Niemiec posiadała 81410 tys. mieszkańców. Tamże, s. 49.

9 Po latach, gdy proces pojednania zakończył się sukcesem, Helmut Kohl przyznał, że to głównie dzięki prozachodniej orientacji polityki zagranicznej RFN udało się zachować międzynarodowe zaufanie do Niemiec. Kohl stwierdził wówczas „Powiązanie z Zachodem było przesłanką tego, aby Niemcy wprowadzić do wspólnoty państw jako równouprawnionego członka. Stworzyło ono ramy dla zagwarantowania pokoju i wolności, dla polityki europejskiej, zjednoczenia oraz porozumienia i przebaczenia z Francją". Za: H. Kohl, Auf dem Weg ins 21. Jahrhundert. Reden zur Regierungspolitik 1997, Bonn 1998, s. 99.

10 Ungewöhnlich schwierig, „Der Spiegel”, 21.01.1991. 
nowe państwo niemieckie postanowiło kontynuować zapoczątkowaną przez Konrada Adenauera politykę proeuropejską, zaś w interesie samej Europy leżało zaangażowanie w umacnianie tej tendencji, zwłaszcza biorąc pod uwagę różnicę pomiędzy znaczeniem politycznym a siłą ekonomiczną tego kraju.

Wraz z rozpadem powojennego ładu Niemcy stanęli w obliczu zasadniczo nowej sytuacji w polityce wewnętrznej i zagranicznej. Dynamika wydarzeń politycznych, które zakończyły się rozpadem Związku Radzieckiego pod koniec 1991 roku, okazała się dla nich bardzo korzystna. Bieg wypadków doprowadził bowiem w 1990 roku do zjednoczenia obu państw niemieckich, a tym samym przyniósł im także, po raz pierwszy po prawie pięćdziesięciu latach, znowu pełną suwerenność. Jak głosił kanclerz Helmut Kohl podczas uroczystości 3 października 1990 roku „Swoją ponownie odzyskaną jednością pragniemy służyć pokojowi na świecie i postępowi w budowie zjednoczonej Europy"1. Niemcy od samego początku popierały więc nie tylko pogłębianie, ale także poszerzanie integracji europejskiej o państwa Europy Środkowo-Wschodniej i Północnej, bowiem leżało to w interesie RFN.

Republika Federalna od momentu jej powołania w 1949 roku uważała za jedynie właściwy kierunek dla swej polityki zagranicznej trwały sojusz ze światem zachodnim, wierząc, że przyszłe zjednoczenie, które stanowiło najważniejszy cel w polityce zagranicznej realizowanej przez administrację bońską, może zostać zrealizowany jedynie wówczas, gdy państwo zachodnioniemieckie zyska zaufanie sojuszników. Stąd żywotne cele polityki zagranicznej Niemiec związane były z europeizacją i budową zjednoczonej, wspólnej Europy. Także po zakończeniu zimnej wojny i zjednoczeniu dwóch państw niemieckich wydawało się, że RFN podąża za mottem wypowiedzianym przez historyka Michaela Stürmera, iż Niemcy muszą stać się „najbardziej europejskim narodem spośród wszystkich Europejczyków" albowiem europejskość jest trwale związana z realizacją niemieckich interesów narodowych ${ }^{12}$.

Postępująca integracja europejska oraz budowa pokojowej Europy utrwalały zarazem rolę Niemiec jako siły napędowej tych procesów, a dla dzieła jednoczenia kontynentu poprzez budowę Unii Europejskiej nie było w polityce europejskiej żadnej alternatywy. Jak wskazywał kanclerz Kohl, integracja była kwestią wojny bądź pokoju, więc konieczne było przezwyciężenie historycznych niemieckich bolączek i wykorzystanie wielkości demograficznej, terytorialnej oraz

11 K. Lau, Kh. Lau (Hrsg.), Einheit in Frieden und Freiheit. Dokumente der Wiedervereinigung Deutschlands, Braunschweig 1991; „Bulletin. Presse- und Informationsamt der Bundesregierung", 05.10.1990.

12 M. Stürmer, Die alten Dämonen tanzen, „Der Spiegel”, 14.01.1991. 
polityczno-gospodarczej dla celów europejskich. Historyk Krzysztof Malinowski ocenił, że „dzieło integracji europejskiej to zwieńczenie niemieckiej trudnej historii XIX i XX wieku, europejska finalité to ucieleśnienie niemieckiej finalité, bezpieczna i arkadyjska przystań dla Niemiec i europejskich narodów. Wydaje się więc, że istnieje bezpośredni związek przyczynowo-skutkowy między sukcesem niemieckiej polityki zagranicznej a sytuacją UE"13.

W rzeczywistości odpowiedź na pytanie o to, czy kraj, który ze wszystkich stron ma wspólną granicę z dziewięcioma państwami europejskimi, może sobie pozwolić na bierny udział w polityce europejskiej, była oczywista, bowiem ze względu na swoje położenie w samym sercu kontynentu Niemcy mogły naturalnie czerpać korzyści z pokojowych i dobrych stosunków sąsiedzkich. A żywotna Europa leżała w politycznym i gospodarczym interesie Niemiec, jako że proces integracji europejskiej stanowił odpowiednie ramy dla zapewnienia pokoju, dobrobytu i bezpieczeństwa.

Obecne Niemcy - niegdyś gospodarczy gigant, ale i polityczny pacjent specjalnej troski, strzeżony przez kilkadziesiąt lat przez cztery mocarstwa - zmieniły się na przestrzeni ostatniego ćwierćwiecza nie do poznania. $\mathrm{Z}$ obiektu integracji europejskiej RFN stała się pod koniec lat 90. ubiegłego stulecia jej głównym podmiotem wyznaczającym kierunek nie tylko w gospodarce, ale i polityce europejskiej, wykorzystując po mistrzowsku retorykę europejską w celu forsowania własnych rozwiązań i postulatów. Wybiwszy się na „niepodległość” i odzyskawszy „normalność” Niemcy znalazły się jednak na rozdrożu gdyż pierwszy raz w powojennej historii zaczęły wychodzić poza określone dotąd w ich polityce zagranicznej ramy europejskie, i domagać się traktowania ich jako „normalnego państwa”, posiadającego własne, narodowe interesy, także poza granicami Starego Kontynentu. Dobrze rozumiał te nowe oczekiwania socjaldemokratyczny kanclerz Gerhard Schröder, który wprawdzie podtrzymywał dzieło poszerzania i pogłębiania europejskiej wspólnoty, jednocześnie jednak uznawał Niemcy za „wielkie mocarstwo" (Grossmacht), świadome swej pozycji i odpowiedzialności na arenie międzynarodowej, którego interesy sięgały znacznie dalej aniżeli do granic Unii Europejskiej czy kontynentu europejskiego. Wydaje się, że takie postrzeganie Niemiec zapoczątkowało ewolucję niemieckiej polityki europejskiej i erozję jednoznacznej identyfikacji interesów Niemiec z europejskimi ${ }^{14}$.

13 K. Malinowski, Przywódcza rola Niemiec $w$ Europie i świecie $w$ niemieckim dyskursie naukowym, „Przegląd Zachodni” 2013, nr 2, s. 28-29.

14 B. Koszel, Hegemon wbrew własnej woli? Problemy i wyzwania dla przywództwa Niemiec $w$ Unii Europejskiej $w$ drugiej dekadzie XXI wieku, „, Rocznik Integracji Europejskiej” 2015, nr 9, s. 265-266. 
Gerhard Schröder, przejmując urząd kanclerza w 1998 roku, był przedstawicielem zupełnie innego pokolenia działaczy politycznych, urodzonych już po II wojnie światowej, nie patrzącego na politykę przez pryzmat winy i odpowiedzialności Niemiec. Stąd też przywiązywał dużą wagę do kierowania się w polityce zagranicznej interesami narodowymi, wykazując większą niezależność i asertywność. To za jego kadencji RFN prezentowała pierwszy raz samodzielnie tak duże aspiracje, by przyspieszyć rozwój procesów integracyjnych na kontynencie, czego efektem było rozpoczęcie ważnej dyskusji na temat finalité politique Unii Europejskiej, w którą zaangażowali się czołowi niemieccy politycy Joschka Fischer, Johannes Rau czy Helmut Schmidt ${ }^{15}$, natomiast przełomem w reformowaniu Unii Europejskiej miała stać się Konstytucja dla Europy, nad której założeniami pracował Konwent w sprawie Przyszłości Europy (Konwent Europejski). Także za czasów kanclerstwa Schrödera Niemcy po raz pierwszy w powojennej historii zaangażowali Bundeswehrę za granicą - w 1999 roku w Jugosławii, a od 2001 roku w Afganistanie ${ }^{16}$. Okres jego rządów przyniósł znaczną reorientację niemieckiej polityki zagranicznej w wymiarze globalnym, także ze względu na rozpoczętą przez Stany Zjednoczone „wojnę z terroryzmem”" ${ }^{17}$. Ataki na USA z 11 września 2001 roku wprawdzie w pierwszych miesiącach po ich dokonaniu skonsolidowały sojuszników amerykańskich we wspólnej walce przeciwko terrorystycznemu ugrupowaniu Al-Kaida, jednak w krótkim czasie doprowadziły do zaskakujących przewartościowań na światowej i europejskiej scenie politycznej. Coraz wyraźniejsze tendencje unilateralistyczne w połączeniu $\mathrm{z}$ forsowaną przez Amerykanów doktryną „uderzenia wyprzedzającego” w zasadniczy sposób zmieniły stosunki transatlantyckie, naświetlając różnice $\mathrm{w}$ podejściu do rozwiązywania międzynarodowych problemów bezpieczeństwa zarówno pomiędzy członkami NATO, jak i samej Unii Europejskiej. Choć operacja antytalibska nie spotkała się w Europie z zastrzeżeniami, amerykańskie plany inwazji na Irak postawiły część państw - w tym także, po raz pierwszy

15 J. Ciesielska-Klikowska, Debata na temat przyszłości Unii Europejskiej na przełomie XX i XXI wieku - stanowisko Republiki Federalnej Niemiec, [w:] E. Kuczyński, M. Tomczyk (red.), Niemcy, Austria, Szwajcaria. Wyzwania z przełomu XX/XXI wieku, Łódź 2012, s. 140-153.

16 Jeszcze na początku XXI wieku kwestia udziału niemieckiej Bundeswehry w zagranicznych misjach wojskowych wzbudza wiele kontrowersji politycznych. Szerzej: K. Malinowski, Przemiany niemieckiej polityki bezpieczeństwa, Poznań 2009.

17 Określenia tego użył prezydent USA George W. Bush w swoim przemówieniu przed połączonymi izbami amerykańskiego Kongresu 21 września 2001 roku. Text of George Bush's speech, Full Text, https://www.theguardian.com/world/2001/sep/21/september11.usa13 (dostęp: 24.05.2016). 
po II wojnie światowej, Niemcy - po drugiej stronie sporu z administracją waszyngtońską, a rząd w Berlinie podkreślał raczej konieczność wielostronnej współpracy i wzrostu znaczenia organizacji międzynarodowych w rozwiązywaniu problemów bezpieczeństwa zagrażających całemu systemowi wartości prezentowanych przez zachodnie demokracje. Ten sprzeciw Republiki Federalnej, starającej się do tej pory utrzymywać constans w relacjach ze swoimi najważniejszymi partnerami, tj. z USA i Francją, był prawdziwym przełomem. Stosunki niemiecko-amerykańskie doznały nieznanego dotąd ochłodzenia. Dla Niemiec, występujących jako przeciwnicy amerykańskiej interwencji w Iraku, stało się jasne, że tylko silna Unia jest w stanie obronić się sama w przypadku zagrożenia jej bezpieczeństwa.

Ten głęboki kryzys w relacjach ze Stanami Zjednoczonymi oraz następujące w tym samym czasie zbliżenie w stosunkach niemiecko-rosyjskich, przyczyniło się do zmniejszenia zaufania sojuszników wobec Niemiec. Fundamentem spektakularnego zacieśnienia współpracy między RFN a Federacją Rosyjską w pierwszej dekadzie XXI wieku stały się przede wszystkim obopólne interesy gospodarcze. Już podczas pierwszej wizyty nowego prezydenta Rosji, Władimira Putina, w Berlinie w 2000 roku uzgodniono szereg porozumień o współpracy między rosyjskim Gazpromem i niemieckimi koncernami w sektorze energetyczno-surowcowym. Jednak najistotniejszym ustaleniem wizyty było powołanie niemiecko-rosyjskiej grupy roboczej wysokiego szczebla ds. strategicznych kwestii współpracy gospodarczo-finansowej, która miała zadbać o długoterminowy rozwój bilateralnych stosunków gospodarczych, określanych jako „partnerstwo strategiczne”. W dwustronnych stosunkach gospodarczych kluczowy charakter zyskała współpraca w sektorze energetycznym. Rząd federalny liczył przede wszystkim na uzyskanie dostępu do rosyjskich złóż naftowo-gazowych i zagwarantowanie dostaw do kraju, ponieważ niemieckie zasoby surowcowe były daleko niewystarczające. Tymczasem Rosji zależało na niemieckich inwestycjach w zagospodarowanie nowych złóż, w rozwój infrastruktury przesyłowej oraz na bezpośrednim dostępie do odbiorców ropy i gazu na europejskim rynku. To partnerstwo strategiczne zwieńczone zostało podpisaniem w 2005 roku porozumienia o budowie gazociągu na dnie Morza Bałtyckiego, któremu stanowczo sprzeciwiał się szereg państw regionu Europy Środkowej i Wschodniej, widząc $\mathrm{w}$ nim zagrożenie dla swoich interesów bezpieczeństwa energetycznego ${ }^{18}$.

18 J. Ciesielska, Gazowa pętla na szyi Europejczyków. Sprawa budowy Gazociąu Pótnocnego w oczach europejskiej opinii publicznej, „Niemcy-Austria-Szwajcaria. Rocznik Katedry Badań Niemcoznawczych Uniwersytetu Łódzkiego”, Łódź 2007, s. 375-392. 
Także relacje z najważniejszym europejskim partnerem Niemiec - Francją - były dość dobre, a oba państwa nie ustawały w wysiłkach związanych z pogłębianiem procesu integracji europejskiej. Problemy lat 90., a w szczególności obawy Francji przed silnymi, bo zjednoczonymi Niemcami, udało się opanować, jednak między politykami z obu stron Renu brakowało tej więzi porozumienia i przyjaźni, jaka łączyła ich wielkich poprzedników. Po przejęciu władzy w RFN przez socjaldemokratów i zielonych w 1998 roku podjęto nawet pierwsze przymiarki do ponownego ożywienia francusko-niemieckiego tandemu. Impulsem było zbliżające się wprowadzenie wspólnej waluty i ambicja osiągnięcia wysokiej pozycji międzynarodowej przez Unię Europejską. Dla zrealizowania tych celów konieczna okazała się ścisła współpraca ministrów finansów, Dominique’a Strauss-Kahna i Oskara Lafontaine’a, którzy wspierali wzajemnie swoje projekty - RFN nie wahała się poprzeć francuskich koncepcji stworzenia „Europy społecznej”, natomiast $\mathrm{V}$ Republika nie odmawiała poparcia w sprawie szybkiego wprowadzenia euro, sztandarowego projektu polityków federalnych ${ }^{19}$.

W styczniu 2001 roku w położonym niedaleko Strasbourga Blaesheim, zorganizowano także nieformalne spotkanie przywódców obu państw i ministrów spraw zagranicznych. Powodem intensyfikacji współpracy była konieczność stworzenia wspólnego stanowiska wobec mającego nastąpić w najbliższych latach rozszerzenia UE, a co za tym idzie nieodzowność zreformowania instytucji unijnych. Mimo dzielących je różnic, oba państwa były bowiem zgodne, że to one „stanowić będą pierwsze ofiary Europy, która nie funkcjonuje" ${ }^{20}$. Podczas szczytu kanclerz Schröder i prezydent Chirac uzgodnili, że co 6 do 8 tygodni będą spotykać się w celu omówienia najważniejszych spraw bilateralnych i europejskich ${ }^{21}$. Seria nieformalnych spotkań, którą nazwano "procesem z Blaesheim”, przyczyniła się do wypracowania przez Berlin i Paryż w kolejnych latach wspólnego stanowiska tak w sprawach unijnych, jak i międzynarodowych, zaś szczególnie silny impuls do połączenia wysiłków na arenie światowej przyniosła planowana przez Stany Zjednoczone inwazja na Irak, której oba państwa były zdecydowanie przeciwne.

Angela Merkel, obejmując w 2005 roku urząd po socjaldemokracie Gerhardzie Schröderze, zapowiedziała zmianę w polityce europejskiej Niemiec, a Berlin miał ponownie całą swoją uwagę skupić na Europie i nowych

19 O. Lafontaine, D. Strauss-Kahn, Tirer le meilleur de l'euro, „Le Monde”, 15.01.1999.

20 H. de Bresson, A. Leparmentier, Europe. Léchecs d'un Européen de raison, „Le Monde”, 13.03.2007.

21 Paris et Berlin réaffirment leur volonté de préparer ensemble l'intégration européenne, „Le Monde”, 02.02.2001. 
rozwiązaniach traktatowych. Nowa kanclerz uznała projekt Konstytucji dla Europy, odrzucony w referendach we Francji i Holandii na wiosnę 2005 roku, za niezmiernie ważny i wart kontynuowania. Stanowisko szefowej niemieckiego rządu podzielał ówczesny prezydent Francji Jacques Chirac. Podczas dwustronnego spotkania w Rheinsbergu 6 czerwca 2006 roku, przywódcy zgodzili się, iż dołożą wszelkich starań, by osiągnąć konsensus w sprawie traktatu $^{22}$. Natomiast pod koniec 2006 roku oba państwa stwierdziły, że nadchodząca prezydencja niemiecka w pierwszej połowie 2007 roku oraz rocznica podpisania Traktatów Rzymskich stanowić będą idealną okazję do opracowania nowych rozwiązań systemowych.

Niemcy razem z Komisją Europejską zaangażowały się w proces pilotowania dyskusji o nowym traktacie. W trakcie spotkania Rady Europejskiej w połowie czerwca 2006 roku podjęto decyzję, że niemiecka prezydencja postawi sobie jako cel przeanalizowanie możliwych rozwiązań instytucjonalnych, co w konsekwencji przyczyni się do podpisania nowego traktatu ${ }^{23}$.

Już w 2006 roku minister spraw wewnętrznych Francji Nicolas Sarkozy proponował, by z Traktatu Konstytucyjnego wyłuskać regulacje, co do których nie ma żadnych zastrzeżeń i przyjąć nowy dokument. Niemcy doskonale zdawali sobie sprawę ze słabości dokumentu. Podkreślali, że daleko mu do zwięzłości, jaką prezentują konstytucje państwowe. Mimo to wychodzili z założenia, że traktat ratyfikowany już przez 16 państw, powinien znaleźć swoje miejsce $\mathrm{w}$ europejskim systemie prawodawczym. Opinię taką podzielała sama kanclerz Merkel, która stwierdziła podczas międzynarodowej konferencji zorganizowanej przez Fundację Bertelsmanna 22 września 2006 roku w Berlinie, że przyjęcie traktatu powinno stać się istotnym zadaniem niemieckiej prezydencji, ale nie sprecyzowała, które z rozwiązań należałoby pozostawić. Była jednak pewna, że istnieją dwie możliwości co do opracowania tekstu nowego traktatu - ponowna wieloletnia dyskusja lub, tak jak proponowała to strona francuska, wykorzystanie bezspornych zapisów i opracowanie jedynie kontrowersyjnych regulacji ${ }^{24}$.

Oczekiwania wobec państwa niemieckiego były tak duże, że fiasko reformy traktatowej odczytane byłoby z pewnością jako klęska niemieckiej wizji Europy i porażka niemieckiego przywództwa. W Berlinie zdawano sobie sprawę, że jeśli nie Niemcy, to nikt inny nie zjednoczy kontynentu nowym

22 Szerzej: EU-Verfassung und Euronext: Blaesheim-Treffen in Rheinsberg, 6. Juni 2006, „Dokumente. Zeitschrift für den deutsch-französischen Dialog” 2006, nr 4.

23 Szczyt Rady Europejskiej w Brukseli. 17-18 czerwca 2005 roku, Urząd Komitetu Integracji Europejskiej, www.ukie.gov.pl (dostęp: 09.05.2016).

24 Merkel już nie mówi o Bogu w europejskiej konstytucji, „Rzeczpospolita”, 23.09.2006. 
traktatem. Kwestia opracowania i przyjęcia zapisów nowego traktatu stała się więc priorytetem $\mathrm{w}$ niemieckim programie prezydencji $\mathrm{w}$ pierwszym półroczu 2007 roku. W dalszej kolejności znalazły się sprawy gospodarczo -energetyczne, relacje ze wschodnimi sąsiadami Unii oraz problemy rynku pracy i polityki społecznej. Agendę przewodnictwa kanclerz Merkel zaprezentowała 14 grudnia 2006 roku przed członkami Bundestagu. Dokument, zatytułowany Europa uda się wspólnie (Europa gelingt gemeinsam), zawierał zapis, iż traktat stanowić będzie „widoczny postęp w Europie zorientowanej na wartości, sprawy społeczne i prawa człowieka" oraz, że nowy akt wzmocni współpracę w ramach Wymiaru Sprawiedliwości i Spraw Wewnętrznych, zintensyfikuje kooperację w ramach Wspólnej Polityki Zagranicznej i Bezpieczeństwa, a także przekształci Unię w organizację bardziej przejrzystą, demokratycznie zarządzaną i skuteczniejszą 25 .

Ostatecznie na szczycie Rady Europejskiej w czerwcu 2007 roku kończącym prezydencję niemiecką przyjęto nowe ustalenia i rozpoczęto prace nad późniejszym Traktatem Lizbońskim. Jego zapisy w pełni odpowiadały niemieckim oczekiwaniom, potwierdzając wysoką pozycję tego państwa w Europie ${ }^{26}$.

Kanclerz Merkel, przejmując obowiązki szefa rządu, w wymiarze polityki zagranicznej RFN chciała kontynuować szczególne stosunki z Francją, jednak, działając już w rozszerzonej od 2004 roku Europie, kładła większy nacisk na wsłuchiwanie się w głos państw regionu Europy Środkowej i Wschodniej, także Polski. Kontynuowane miało być partnerstwo strategiczne z Rosją, w tym budowa Gazociągu Północnego - jednak w przeciwieństwie do Schrödera, Merkel podjęła się próby rozmowy na temat projektu z krajami regionu bałtyckiego w celu wyjaśnienia ich wątpliwości. Nowy rząd starał się ponadto o poprawę stosunków ze Stanami Zjednoczonymi oraz postawił na rozwój współpracy dwustronnej z mocarstwami wschodzącymi - m.in. Chinami, Indiami i Brazylią.

Dekada Angeli Merkel stała się okresem wyjątkowo pomyślnym dla Niemiec. Wskutek przeprowadzonych jeszcze przez gabinet Gerharda Schrödera reform gospodarczych w ramach pakietu „Agenda 2010” sytuacja gospodarcza zaczęła się poprawiać, a bezrobocie znacząco spadło. Trudne

25 „Europa gelingt gemeinsam”. Präsidentschaftsprogramm 1. Januar-30. Juni 2007, Politisches Programm der deutschen Bundesregierung für die Ratspräsidentschaft 2007, http://eu2007.de/includes/Downloads/Praesidentschaftsprogramm/EU-P-AProgr -d-2911.pdf (dostęp: 09.05.2016).

26 J.J. Węc, Traktat lizboński. Polityczne aspekty reformy ustrojowej Unii Europejskiej w latach 2007-2009, Kraków 2011. 
i niepopularne decyzje, które poprzedni gabinet przypłacił utratą władzy, wraz z pakietami ratunkowymi przyjętymi przez kanclerz Merkel, przyczyniły się do uchronienia Niemiec przed długotrwałą recesją wskutek światowego kryzysu gospodarczego.

Kryzys finansowy, który wybuchł na jesieni 2008 roku w Stanach Zjednoczonych, szybko przemieścił się z USA do najbogatszych krajów świata zachodniego, w tym do Niemiec, przybierając formę jednego $z$ najpoważniejszych kryzysów gospodarczych w historii. Kryzys ekonomiczny, który w konsekwencji doprowadził także do poważnego kryzysu w strefie euro, spowodował przedefiniowanie niemieckiego postrzegania Europy oraz wzmocnienie dotychczasowych tendencji do poszukiwania partnerów poza Starym Kontynentem. W konsekwencji, świetnie prosperujące gospodarczo Niemcy urosły do rangi niekwestionowanego lidera w zakresie polityki ekonomicznej w UE, a mimo że decyzje na szczeblu Rady Europejskiej podejmowane są na zasadzie konsensu wszystkich państw członkowskich, powszechną stała się opinia, że to właśnie Berlin nadaje ton dyskusjom gospodarczym w Brukseli. Lansowana przez kanclerz Angelę Merkel „polityka austerity” stała się nadrzędną polityką realizowaną przez instytucje unijne, starające się walczyć ze skutkami kryzysu. Stało się tak, mimo że wielu liderów państw członkowskich UE, zwłaszcza tych z południa Europy, wyrażało swój sprzeciw wobec wprowadzania drastycznych cięć i rygorystycznych wymogów oszczędności, twierdząc, że blokują one wszelkie inicjatywy pobudzające gospodarkę.

$\mathrm{Na}$ tak wysoką pozycję Niemiec w kształtowaniu polityki europejskiej w dziedzinie ekonomii bez wątpienia wpłynęła siła niemieckiej gospodarki oraz jej dobre wyniki w ostatnich latach. Podczas gdy większość Europy, a zwłaszcza strefa euro, przeżywała recesję i zmagała się z coraz wyższym bezrobociem, Niemcy - z niską stopą bezrobocia i rozwijającym się przemysłem - wyszły z kryzysu bez większych problemów, odskoczyły niejako od reszty europejskiego peletonu i stały się gospodarczą siłą napędową Starego Kontynentu.Dzięki polityce prowadzonej przez rząd kanclerz Merkel szybko rozwijał się handel zagraniczny, zwłaszcza eksport, coraz szybciej także rosła nadwyżka w wymianie z zagranicą, przekraczając w 2014 roku barierę 200 miliardów euro. Ostatnie sukcesy handlowe Niemiec wyraźnie wskazują, jak korzystna okazała się dla nich wspólna waluta, zwiększająca opłacalność niemieckiego eksportu w skali globalnej.

Niewątpliwie Niemcy od momentu wybuchu kryzysu gospodarczo-finansowego konsekwentnie forsowały swoje rozwiązania, kierując się niekoniecznie interesem europejskim, lecz własnym, niekiedy wręcz na szkodę zadłużonych państw strefy euro, co przyznał niemiecki Instytut Badania Gospodarki 
w Halle (Leibniz-Institut für Wirtschaftsforschung Halle, IWH) wykazując, że Niemcy stały się najważniejszym „beneficjentem” kryzysu finansowego w Europie, w szczególności w kontekście kryzysu w Grecji ${ }^{27}$. Zdaniem berlińskiej administracji rozwiązaniem dla kryzysu gospodarczego w krajach strefy euro miała być dyscyplina finansowa oraz reformy strukturalne wzorowane na niemieckim modelu społeczno-gospodarczym. Jak się jednak okazało to, co świetne rezultaty przyniosło nad Renem, nie działało jednakowo dobrze w innych krajach, posiadających odmienną specyfikę. Pomijając kwestię słuszności uzdrowienia gospodarki greckiej koniecznymi reformami, wielu ekonomistów podkreślało przede wszystkim potrzebę zadbania o wzrost gospodarczy oraz zwalczanie bezrobocia. Zaś niemiecką receptę dla Grecji, rozumianą jako „politykę zaciskania pasa”, jako kontrskuteczną wielokrotnie krytykowano - czynił to m.in. Międzynarodowy Fundusz Walutowy oraz amerykański noblista w dziedzinie ekonomii Joseph E. Stiglitz, który sugerował wręcz, iż kłopoty Grecji wynikają częściowo z proeksportowej polityki Niemiec $^{28}$.

Światowy kryzys gospodarczy spowodował, że Niemcy jako najważniejsze państwo strefy wspólnej waluty stały się centrum polityki europejskiej. Kanclerz Merkel prowadziła coraz skuteczniejszą politykę zagraniczną i coraz pewniej poruszała się na europejskich i światowych salonach. Wskazywała, że w swojej działalności kieruje się przesłaniem in dubio pro Europa, choć jej działaniom przyglądano się z coraz większą podejrzliwością ${ }^{29}$. W 2013 roku Gertrud Höhler, pisała krytycznie, że „im gorsza była sytuacja Europy, tym lepiej powodziło się Niemcom [...] Europa sięgnąwszy dna była gotowa na przyjęcie koncepcji władzy Merkel, a Merkel szykowała się do rządzenia Europą"30.

W 2012 roku z inicjatywy Berlina przegłosowano w Unii Europejskiej tzw. Pakt Fiskalny, zobowiązujący państwa do przestrzegania zasad dyscypliny finansowej. Dopiero wskutek rosnącej europejskiej „opozycji przeciw oszczędnościom" pod wodzą nowego prezydenta Francji François Hollande’a Pakt Fiskalny uzupełniono o Pakt na rzecz wzrostu gospodarczego i zatrudnienia, który miał dać impulsy do wzrostu gospodarczego państw strefy euro. Mimo dążeń Paryża i innych stolic, nie udało się jednak przekonać Berlina do emisji euroobligacji, które kanclerz Merkel uznała za sprzeczną z interesami Niemiec formę uwspólnotowienia długów. Hans Kundnani z European Council

27 IHW: Niemcy sq „wielkim beneficjentem” kryzysu w Grecji, „Gazeta Wyborcza”, 15.08.2015.

J. Żakowski, Kto drukuje, ten żyje. Wywiad z J. E. Stiglitzem, „Polityka”, 30.07.2013.

B. Koszel, dz.cyt., s. 282.

30

G. Höhler, Matka chrzestna. Jak Merkel przebudowuje Niemcy, Poznań 2013, s. 115-116. 
on Foreign Relations, autor głośniej książki The Paradox of German Power tłumaczył wówczas, że Niemcy stoją przed sprzecznymi interesami - z jednej strony chcą utrzymać strefę euro, $\mathrm{z}$ drugiej zaś strony nie są gotowe zrobić tego, co jest konieczne, aby ten cel osiągnąćc $c^{31}$.

Nieustępliwość Berlina w kwestii forsowania niemieckich recept dla pogrążonych w kryzysie krajów stała się przyczyną rosnącej niechęci do Niemiec i osobiście do kanclerz Merkel w wystawionych na bolesne reformy społeczeństwach. Ów upór zrodził krytykę, że Berlin, wymuszając korzystne dla siebie rozwiązania, zapomina o pielęgnowanej w Unii Europejskiej kulturze kompromisu i wysłuchiwania racji innych, czego przykładem stały się m.in. negocjacje z Grecją, które zakończyły się de facto zmuszeniem do przystania na warunki międzynarodowych kredytodawców; czy kwestia kwotowego podziału uchodźców. W tej sprawie w istocie kanclerz Merkel popełniła błąd, ogłaszając otwarcie granic, co spotęgowało niekontrolowany napływ imigrantów i wysłało sygnał, że są oni w Europie mile widziani. Jednocześnie Berlin, nie zwracając uwagi na argumentację państw Europy Środkowej i Wschodniej, które jako kluczową sprawę stawiały zabezpieczenie granic wspólnotowych i powstrzymanie fali uchodźców, próbował przeforsować odgórny podział migrantów między kraje unijne „w imię europejskiej solidarności". Zwrócił na to uwagę były ambasador Polski w RFN Janusz Reiter, który w artykule dla dziennika „Frankfurter Allgemeine Zeitung” krytykował wywierany przez rząd federalny nacisk i nawoływał Niemcy, by nie kierowali się $\mathrm{w}$ tej sprawie emocjami, lecz chłodnym realizmem ${ }^{32}$.

Analizując przywódczą rolę RFN w UE warto zauważyć, że Berlin, choć zwykle podejmuje decyzje w pojedynkę, często próbuje ukryć swoją rolę, wskazując na szerokie poparcie dla swoich postulatów, lub uzgadniając je najpierw z Paryżem, by później przedstawiać je jako najlepszy kompromis dla UE. Choć w 2012 roku zmienił się prezydent Francji, to nadal tandem francusko-niemiecki stanowi o przyszłości Europy. Wprawdzie w pierwszych miesiącach od objęcia urzędu prezydenta V Republiki Francuskiej François Hollande wyraźnie nie widział w Angeli Merkel „zbawczyni Europy” i wielokrotnie dawał publicznie sygnały, że nie jest entuzjastą wizji kanclerz Merkel, zmuszającej do ciągłego oszczędzania i duszenia gospodarek, to w kolejnych latach widać było wyraźnie, jak przywódca Francji - z bardzo słabym

31 G. Hillgruber, Geoökonomischer Halbhegemon?, „Frankfurter Allgemeine Zeitung”, 25.04.2016.

32 J. Reiter, Deutschland braucht mehr Realismus, „Frankfurter Allgemeine Zeitung”, 23.09.2015. 
społecznym poparciem wynoszącym ledwie kilkanaście procent ${ }^{33}$ - szukał możliwości porozumienia się z Niemcami i odgrywania wciąż istotnej roli na arenie międzynarodowej. W istocie prezydent Hollande stał się w ostatnim czasie lojalnym sojusznikiem i partnerem kanclerz Merkel, a oboje przywódcy często konsultują się ze sobą, prezentując wspólne stanowisko. Niemniej nie ma wątpliwości, iż głównym rozgrywającym w tym tandemie pozostają Niemcy. Francja służy Niemcom w znacznej mierze do dzielenia się odpowiedzialnością i uniknięcia wrażenia, że działają sami. Tymczasem dla Francji współpraca z RFN oznacza podtrzymanie dotychczasowego prestiżu bycia współliderem, wedle formuły wypowiedzianej przez byłego prezydenta Francji Nicolasa Sarkozy'go „Bez Francji Niemcy przerażają wszystkich. Bez Niemiec Francja nie przeraża nikogo" ${ }^{34}$.

Jak w swojej książce Niemiecka Europa z 2013 roku pisał znany niemiecki socjolog Ulrich Beck, „Niemcy jako potęga gospodarcza wysunęły się na pozycję politycznego lidera, decydującego o losie państw Południa i całej UE”, opisując wzrost roli Berlina podczas kryzysu finansowego w strefie euro. Rzeczywiście, teza Becka, iż aktualnie mamy „europejskie Niemcy w niemieckiej Europie", dobrze oddaje opinie, jakie od kilku lat pojawiają się w publicznym dyskursie dotyczącym przywództwa niemieckiego w Unii Europejskiej w XXI wieku's

Również znany filozof Jürgen Habermas zwraca uwagę, że rząd Angeli Merkel przebudowuje Stary Kontynent „na niemiecką modłę”, żałując, że dawna wizja nastawionych na kooperację i kompromis europejskich Niemiec zastępowana jest przez „nieskrywaną chęć przywództwa”, a dyplomatyczna powściągliwość RFN stopniowo ustępuje takim działaniom w ramach Unii Europejskiej, które wskazują na coraz mniejszą wrażliwość na interesy innych państw. Habermas ocenia, że w ostatnich latach to nie Bruksela narzuca jakieś rozwiązania, ale coraz bardziej Berlin ${ }^{36}$.

33 Sondaż: François’a Hollande’a popiera 16 proc. Francuzów, „Rzeczpospolita”, 05.05.2016; François Hollande zyskuje poparcie Francuzów mimo zamachu w Nicei, „Newsweek”, 24.07.2016; Hollande bez poparcia. Blisko 80 proc. Francuzów nie chce, by startowat w wyborach, „Gazeta Wyborcza”, 07.09.2015.

D. Seux, L’Allemagne fait-elle peur et la France rire?, „Les Echos”, 06.11.2013.

J. Habermas, Pakt dla Europy czy przeciw Europie?, „Gazeta Wyborcza”, 09-10.04.2011; H. Wagner, Jürgen Habermas - seine Vision von Europa, „Krakowskie Studia Międzynarodowe" 2012, nr 3. 
Jednak jak wskazuje brytyjski socjolog Anthony Giddens, „niemiecka Europa” nie jest stanem, który będzie się długotrwale utrzymywał. To „tymczasowy i niestabilny układ z konieczności", będący odpowiedzią na nieudolność struktur UE i słabość innych liderów w obliczu ostatnich problemów ${ }^{37}$. Wydaje się bowiem, że nikt inny prócz Niemiec nie był w stanie wziąć na siebie roli lidera w Europie. Już w pierwszych miesiącach po wybuchu kryzysu gospodarczego pojawiały się w Unii Europejskiej głosy wzywające Berlin do wzięcia na siebie większej odpowiedzialności za losy kontynentu. Jednym z najbardziej znamiennych zaś był głos polskiego ministra spraw zagranicznych Radosława Sikorskiego, który występując w Berlinie w listopadzie 2011 roku wypowiedział ważne słowa „mniej obawiam się niemieckiej siły, niż niemieckiej bezczynności"38.

Tymczasem brytyjski politolog Timothy Garton Ash pisał, że Niemcy wcale nie dążyły do uzyskania przywódczej roli w UE, a jej przyjęcie wyniknęło z konieczności, albowiem tylko Berlin był zdolny ją podjąć ${ }^{39}$. Jeszcze w latach 80. zeszłego stulecia o niemieckiej roli w Europie ceniony politolog Christian Hacke pisał, że są „hegemonem wbrew własnej woli” (Hegemon wider Willen), które to stwierdzenie powtórzył już po zjednoczeniu Nie$\operatorname{miec}^{40}$. To samo zdanie wypowiadał potem znany publicysta Stefan Kornelius, który także pisał o Niemczech jako o „hegemonie wbrew własnej woli” ${ }^{41}$. To z jednej strony siła Niemiec i osobiste zdolności pani kanclerz, nazwanej wkrótce „cesarzową Europy”, a z drugiej strony słabość innych zadecydowały o dzisiejszej roli Berlina ${ }^{42}$.

Obecna przywódcza rola Niemiec, określana niekiedy mianem hegemonii, rodzi frustrację w Europie. Można przypuszczać, że jest kwestią czasu, kiedy w stosunku do RFN ukształtuje się zdolna zrównoważyć niemiecką siłę europejska opozycja. Przestrzegał przed tym m.in. były szef niemieckiej dyplomacji Joschka Fischer, mówiąc, iż „Europa nigdy nie zadziałała na

37 A. Giddens, Europa. Burzliwy i potężny kontynent, Warszawa 2014.

38 R. Sikorski, Polska a przyszłość Unii Europejskiej, Berlin 28.11.2011, Ministerstwo Spraw Zagranicznych RP: www.msz.gov.pl/resource/c2a33d88-7b8d-4fa5-8680-a67a4b2b38af: JCR (dostęp: 20.05.2016).

39 T.G. Ash, Allein kriegen sie es nicht hin, „Der Spiegel”, 13.02.2012.

40 Ch. Hacke, Weltmacht wider Willen. Die Ausenpolitik der Bundesrepublik Deutschland, Stuttgart-Frankfurt/M. 1988.

41 S. Kornelius, Hegemon wider Willen, „Süddeutsche Zeitung”, 28.11.2010.

42 M. Kędzierski, Europejskie Niemcy w niemieckiej Europie - wzrost roli zjednoczonych Niemiec $w$ UE, Portal Spraw Zagranicznych, http://psz.pl/117-polityka/europejskie-niemcy -w-niemieckiej-europie-wzrost-roli-zjednoczonych-niemiec-w-ue (dostęp: 20.05.2016). 
zasadzie hegemonii. Jeśli tylko ktoś chce być hegemonem, wszyscy lub prawie wszyscy w Europie jednoczą się przeciw niemu. Unia nie wypali więc nigdy jako projekt niemiecki”"33. Jeśli już pojawi się taka opozycja, wówczas znów stanąć może przed Berlinem znany dylemat, że Niemcy są duże na Europę, ale za małe na świat.

\section{Zusammenfassung}

Der Artikel beschäftigt sich mit der Rolle Deutschlands in der Europäischen Union. Beschrieben werden u.a. deutsches Engagement für die Entwicklung der europäischen Integration, die Gründe und Ursachen dafür, sowie Argumente der BRD in der Diskussion über die Zukunft Europas. Die Autorin versucht dabei, ihre aktuelle Rolle in der Europäischen Gemeinschaft aufzuzeigen und gleichzeitig zu erörtern, ob und wie sich die deutsche Position auf der europäischen Bühne geändert hat. Bei der Suche nach Antworten sind die vielen Nuancen deutscher und europäischer Politik zu berucksichtigen, umso mehr als die Bedeutung von Berlin wie auch von wichtigsten Persönlichkeiten der politischen Szene sich weiter entwickelt und ständig ändert.

\section{Bibliografia}

ASH T.G., W imieniu Europy. Niemcy i podzielony kontynent, Londyn 1996.

BECK U., Niemiecka Europa, Warszawa 2013.

CIESIELSKA J., Gazowa pętla na szyi Europejczyków. Sprawa budowy Gazociagu Północnego w oczach europejskiej opinii publicznej, [w:] Niemcy-Austria-Szwajcaria. Rocznik Katedry Badań Niemcoznawczych Uniwersytetu Łódzkiego, Łódź 2007.

CIESIELSKA-KLIKOWSKA J., Debata na temat przyszłości Unii Europejskiej na przełomie XX i XXI wieku - stanowisko Republiki Federalnej Niemiec, [w:] Kuczyński E., Tomczyk M. (red.), Niemcy, Austria, Szwajcaria. Wyzwania z przełomu XX/XXI wieku, Łódź 2012.

EU-VERFASSUNG und Euronext: Blaesheim-Treffen in Rheinsberg, 6. Juni 2006, „Dokumente. Zeitschrift für den deutsch-französischen Dialog” $2006 \mathrm{nr} 4$.

GIDDENS A., Europa. Burzliwy i potężny kontynent, Warszawa 2014.

HACKE Ch., Weltmacht wider Willen. Die Außenpolitik der Bundesrepublik Deutschland, Stuttgart-Frankfurt/M. 1988.

HÖHLER G., Matka chrzestna. Jak Merkel przebudowuje Niemcy, Poznań 2013.

${ }^{43}$ J. Fischer, Niemcy są za duże na Europę, „Newsweek”, 15.11.2013. 
KOHL H., Auf dem Weg ins 21. Jahrhundert. Reden zur Regierungspolitik 1997, Bonn 1998.

KOSZEL B., Hegemon wbrew własnej woli? Problemy i wyzwania dla przywództwa Niemiec w Unii Europejskiej w drugiej dekadzie XXI wieku, „Rocznik Integracji Europejskiej” 2015, nr 9.

KOSZEL B., Mitteleuropa rediviva? Europa Środkowo- i Południowo-Wschodnia $w$ polityce zjednoczonych Niemiec, Poznań 1999.

LEIMBACHER U., Westeuropäische Integration und gesamteuropäische Kooperation, „Aus Politik und Zeitgeschichte” 1991, nr 45.

MALINOWSKI K., Przemiany niemieckiej polityki bezpieczeństwa, Poznań 2009.

MALINOWSKI K., Przywódcza rola Niemiec $w$ Europie i świecie w niemieckim dyskursie naukowym, „Przegląd Zachodni” 2013, nr 2.

MITTERRAND F., De l'Allemagne, de la France, Paris 1996.

STOLARCZYK M., Podział i zjednoczenie Niemiec jako element ładów europejskich po drugiej wojnie światowej, Katowice 1995.

WAGNER H., Jürgen Habermas - seine Vision von Europa, „Krakowskie Studia Międzynarodowe" 2012, nr 3.

WĘC J.J., Traktat lizboński. Polityczne aspekty reformy ustrojowej Unii Europejskiej w latach 2007-2009, Kraków 2011.

ŻAKOWSKI J., Kto drukuje, ten żyje. Wywiad z J. E. Stiglitzem, „Polityka” 30.07.2013.

www.ukie.gov.pl

www.psz.pl 